\title{
THE BALANCE BETWEEN ISLAMIC LAW, CUSTOMARY LAW AND HUMAN RIGHTS IN ISLAMIC CONSTITUTIONALISM THROUGH THE PRISM OF LEGAL PLURALISM
}

\author{
Anicée Van Engeland*
}

\begin{abstract}
This article examines how the inclusion or exclusion of Islamic law and Muslimbased customary law affects de facto or de lege universal human rights. The view adopted is that there is an Islamic form of constitutionalism that should respect Islam, Shari'a law and Muslim customary law. The author therefore suggests a different approach to constitution-making than the transnational constitutional theory and secular theories, looking at the interaction between sources of law and the role for legal pluralism. The originality of the article is to be found in the demonstration that Islamic constitutionalism is not a threat to transnational constitutionalism, or a competitor, but an alternative. The argument is that a constitutional inclusion of Islamic law and Muslim-based customary law is possible if the authoritative sources of Islam are interpreted in the light of the new hermeneutics of Shari'a law. Islamic law and Shari'a-based customary law need to be reformed, taking international human rights law as a yardstick. This approach to interpretation can then promote a more human-rights oriented reading of Islamic legal sources. The aim is to ensure that the Constitution is legitimate in the eyes of all while ensuring that legal pluralism does not undermine State law and violate universal human rights.
\end{abstract}

\section{Introduction}

The question of whether or not to include Islamic law in a constitution is a recurrent issue with significant implications for human rights. ${ }^{1}$ Islamic

Lecturer, School of African and Oriental Studies

1 See e.g.: H Travis, 'Freedom of Theocracy?: Constitutionalism in Afghanistan and Iraq' (2005) 3 JIHR 1; L C Backer, 'God(s) Over Constitutions: International and Religious Transnational Constitutionalism in the 21st Century' (2008) 27 Miss L Rev 11; A M Emon, 'The Limits of Constitutionalism in the Muslim World: History and Identity in Islamic Law' (2008) Constitutional Design for Divided Societies; Islamic Law and Law of Muslim World Paper No. 08-09 <http://ssrn.com/abstract=1086767> [accessed 13 December 2014].

Copyright $\odot$ the Author(s).

This work is licensed under a Creative Commons Attribution-NonCommercial-NoDerivs 3.0 License. 
law contains norms that bear on human rights such as gender equality and the rights of religious minorities, and these may conflict with both domestic constitutional human rights norms and international human rights norms, for example under the 1948 Universal Declaration of Human Rights. Considering Islamic law also raises the issue of the place human rights norms derived from international instruments such as the Universal Declaration have in domestic constitutions. The focus of academic analysis is usually on the consequences of the constitutional inclusion of Islamic law for universal human rights; yet, customary law is another important element coming into play de lege and de facto. Customary law inspired by Shari'a law can be a source of law acknowledged and included in a constitution; ${ }^{2}$ customary law can also be a competitor to State law, particularly when it is excluded from the constitution. In this article, I analyse the potential effects of including Islamic law in a constitution, but also examine the impact of the constitutionalisation of Islamic law with regard to this other source of law, i.e. customary law as influenced by Shari'a law (hereinafter 'Muslim customary law').

Some scholars have been criticised for approaching constitutionalism of Islamic law from a western perspective, using so-called western-based principles such as democracy, secularism and human rights to understand the role of religious law and customary law in Muslim constitutions. ${ }^{3}$ In this article, I seek to demonstrate that there is a set of ideas in Islamic constitutionalism emerging from Islamic law, Shari'a law and Muslim customary law. I seek to reformulate the debate about constitution-making within the context of an Islamic framework, looking at the interaction between Islamic law and Muslim customary law and the role for legal pluralism.

This contributes to the debate on constitution-making by seeking to demonstrate that Islamic constitutionalism is not a threat to transnational constitutionalism, nor even a competitor, but an alternative. ${ }^{4}$ Many have understood reli-

\footnotetext{
2 The academic debate as to what Shari' means is not analysed in this paper. Shari'a law is defined in this article as a religious code which sets outs rights and duties which are morally and legally inspired. This broad definition also includes behaviours modeled after the Shari'a, as well as behaviours believed to be modeled after the Shari'a.

3 The academic debate as to what Shari'a means is not analysed in this paper. Shari'a law is defined in this article as a religious code which sets outs rights and duties which are morally and legally inspired. This broad definition also includes behaviours modeled after the Shari'a, as well as behaviours believed to be modeled after the Shari'a.

${ }^{4}$ LC Backer, 'Theocratic Constitutionalism: An Introduction to a New Global Legal Order' (2009) 16 Ind J Global Legal Stud 85, 104; R Hirschl, 'The Theocratic Challenge to Constitution Drafting in Post Conflict States' (2008) 49 Wm \& Mary LR, 1179, 1181.
} 
gious law to be an obstacle to the existence of a constitution as supreme law. ${ }^{5}$ Yet, this monist approach of the law does not take into account the social factors attached to the resilience of Islamic law and Muslim constitutions as sources of law. For this reason, a legal pluralist approach is preferable to the transnational constitutionalist theory which, as stressed by Baderin, ${ }^{6}$ focuses on a liberal monist system. I adopt a novel position with regard to the debate on the constitutional inclusion of Islamic law and Muslim customary law, adopting an adjusted legal pluralist stance which supports a new hermeneutics of Shari'a law. The theory of a new hermeneutics of Shari'a law has been developed since the $19^{\text {th }}$ century and argues for a context-based reading of Islamic legal sources such as the Quran and the Sunna. ${ }^{7}$ This then allows Muslim-inspired legislation to keep pace with modern legal issues such as women's rights, surrogacy, or cyber terrorism. This new approach to interpretation, situated within the historical tradition of $i j t i h a d,{ }^{8}$ can then promote a more human-rights oriented reading of Islamic legal sources. This has been used, for example, to develop gender-orientated understandings of the Islamic sources of law. ${ }^{9}$ This new hermeneutics allows for a mitigation of conservative or hardline classical interpretations of the traditional Islamic sources of law.

In contrast to the models presented by transnationalist constitutional scholars, ${ }^{10}$ I argue that the only Muslim constitution which is legitimate is one that takes into account Islamic law and Muslim customary law as sources of law. ${ }^{11}$ The concept of 'cultural legitimacy', as theorised by An Na'im, is crucial when developing a constitution, as the relevant society needs to support the constitution and give it cultural legitimacy. ${ }^{12}$ The revised pluralist approach advocated in this article illustrates the concept of normative pluralism raised by William Twining,

5 See for example Backer, above $\mathrm{n} 1$.

${ }^{6}$ M A Baderin, 'Islamic law and Constitutionalism in Africa: Challenges and Prospects' (2011), ANCL Conference on African Constitutionalism, 'Present Challenges and Prospects for the Future', Faculty of Law, Pretoria, 1-4 August 2011.

7 The Sunna is made up of the deeds and sayings of the Prophet Muhammad.

${ }^{8}$ Ijtihad is the process of interpretation of Islamic legal sources.

9 See e.g. Amina Wadud, Qur'an and Woman: Rereading the Sacred Text from a Woman's Perspective (1999).

${ }^{10}$ See e.g. Amina Wadud, Qur'an and Woman: Rereading the Sacred Text from a Woman's Perspective (1999).

${ }^{11}$ For a review of the different academic stances, see N Sultany, 'Against Conceptualism: Islamic Law, Democracy and Constitutionalism in the Aftermath of the Arab Spring' (2013) 31 BU Int LJ 435.

${ }^{12}$ R Shaham, 'Custom, Islamic law, and Statutory Legislation: Marriage Registration and Minimum Age at Marriage in the Egyptian Sharia Courts' (1995) 2 Islamic L \& Soc 258. 
who sees legal pluralism as a species of normative pluralism. ${ }^{13}$ This approach follows John Griffith's early definition of legal pluralism as a state of affairs in which behaviour pursuant to more than one legal order occurs. ${ }^{14}$ The aim of the article is to comprehend whether this call for legitimacy under legal pluralism undermines State law and whether the conflict between positive Islamic law and customary law weakens a constitution, especially when it comes to the respect and enforcement of universal human rights.

\section{Analysis of the Role of Islamic Law in Constitutions}

It is important to consider the weight and role of Islamic law and customary law in a country when developing a new constitution for that country. While this assessment is now part of most constitutional endeavours, conflicts between different sources of law need to be understood and interpreted in a new framework for the creation of a successful pluralist constitutional system. In this section, I will first analyse the role of Islamic law in developing a constitution and enforcing it, before going on to engaging with the tensions that arise between different sources of law in this process. The purpose of this analysis is to demonstrate that there are legitimate reasons to include Islamic law in the constitution of a Muslim country, as it is reflective of the identity and values within the political community. However, this religion-inclusive shift is not without consequences when the constitutions are actually put into use. In such constution, the clauses on Islamic law often find themselves at odds with human rights-based constitutional values.

\subsection{Considering Islamic law when Developing a Constitution: Motives for Including Religious Law in a Constitution}

The inclusion of religious law into a constitution is not a new phenomenon, and is not specific to the Muslim world. ${ }^{15}$ Yet, it is in the Muslim world that countries have most directly engaged with the inclusion of a divine, historically received

\footnotetext{
${ }^{13}$ W Twining, 'Legal Pluralism 101' in B Z Tamanaha, C M Sage \& M J V Woolcock (eds), Legal Pluralism and Development: Scholars and Practitioners in Dialogue (2012) 112, 116.

${ }^{14}$ J Griffiths, 'What is Legal Pluralism?'(1986) $24 \mathrm{~J} \mathrm{of} \mathrm{L} \mathrm{Pluralism} \mathrm{1,} 2$.

${ }^{15}$ R Hirschl, Constitutional Theocracy (2010) 2.
} 
body of law within the constitutional framework of a modern nation-state. ${ }^{16}$ As a result, Islamic constitutionalism is the most developed form of contemporary religious constitutionalism. The Islamic Republic of Iran illustrates this will to enforce Islamic law in the Preamble and Article 2 of its Constitution. ${ }^{17}$ Other examples include Article 2 of the Constitution of Egypt, Article 2 of the Iraqi Constitution and Article 3 of the Brunei Constitution. ${ }^{18}$ Ahmed and Ginsburg have called these articles 'Islamic supremacy clauses'. ${ }^{19}$ Others have described this process as 'constitutional Islamisation" ${ }^{20}$ and Hirschl refers to the concept as one of 'constitutional theocracy.' ${ }^{21}$ There is an important difference, however, between constitutions in which Islamic law constitutes 'a' source of the law and those in which it constitutes 'the' source of law (that is, the ultimate criterion of legal validity as in cases of Islamic supremacy clauses). Difficulties arise for constitutionalism in either case: a constitution which considers Islamic law as 'the' source of law will not leave room for any other source of law, whereas a constitution which tolerates multiple sources of law, including Islamic law, will face challenges in determining the interactions between these sources, and ultimately the hierarchy between them in the case of conflict.

There are different motivations behind the decision to include Islamic law as 'a' or 'the' source of law in a constitution. Islamic constitutionalism has its roots in the history of Islam and Islamic law, and as such, one motivation is

${ }^{16}$ C B Lombardi, 'Constitutional Provisions Making Shari'a 'a' or 'the' Chief Source of Legislation: Where did they Come from? What do they Mean? Do they Matter?' (2013) 28 Am U Int Rev. 743, 733.

${ }^{17}$ Article 2 of the Iranian Constitution: The Islamic Republic is a system based on belief in: 1) the One God (as stated in the phrase "There is no god except Allah"), His exclusive sovereignty and right to legislate, and the necessity of submission to His commands; 2) Divine revelation and its fundamental role in setting forth the laws;(...) 4) the justice of God in creation and legislation.

${ }^{18}$ Article 2 of the Egyptian Constitution: 'Islam is the religion of the State and Arabic is its official language. The principles of Islamic Sharia are the main source of legislation.'

Article 2 of the Iraqi Constitution: 1. Islam is the official religion of the State and is a foundation source of legislation: A. No law may be enacted that contradicts the established provisions of Islam; B. No law may be enacted that contradicts the principles of democracy; C. No law may be enacted that contradicts the rights and basic freedoms stipulated in this Constitution.

Article 3 of the Brunei Constitution: (4) For the purpose of this Article, His Majesty the Sultan and Yang Di-Pertuan may, after consultation with the Religious Council, but not necessarily in accordance with the advice of that Council, make laws in respect of matters relating to the Islamic Religion.

${ }^{19}$ N Feldman, The Fall and Rise of the Islamic State (2008) 6.

${ }^{20}$ Ibid.

${ }^{21}$ Hirschl, above $\mathrm{n} 4$. 
the desire to rely on and give effect to Islamic law in the constitution from a historical perspective. It ensures continuity with the polity doctrine developed by Muslim scholars regarding state and society: the Prophet's intention was to build an Islamic society in which the law played a predominant role in shaping the interactions between citizens, but also in supporting the role of the leader of that society (The Prophet himself at the time). ${ }^{22}$ Reliance on Islamic law in the $21^{\text {st }}$ century is a clear signal that countries adopting an Islamic supremacy clause, or including Islamic law as 'a' source of law among others, wish to locate their existence within this historical continuity, despite the abolition of the Caliphate in 1924. Including Islamic law in a constitution is also a way for a country, or a leader to ensure legitimacy, that is, the historical legitimacy granted by a centuries-old religion. This is illustrated by the maneuvres operated by President Anwar Sadat in Egypt when attempting to win the support of Islamists: he amended the Constitution of Egypt to include 'the principles of Islamic Shari'a' as 'a primary source of legislation' ${ }^{23}$

The emergence of the nation-state as the primary mode of social organisation and the spread of codification by scholars like al-Sanhuri have compelled the Muslim world to adapt via the codification of Islamic law. Including an Islamic law constitutional clause, then, illustrates a desire to ensure the enforcement of Islamic law in a Muslim state while adapting to the $21^{\text {st }}$ century's nation-state reality; it reflects the choice to continue developing Islamic law through the medium of constitutional law and to seek its enforcement within a Muslim society, adapting it to modern demands. This is why one can speak of 'Islamic constitutionalism' as a historical identity which has been modernised to meet modern challenges. When the Ottomans began reforming Islamic law to adapt it to the modernising expectations of their times, they partly changed the format of Islamic law through codification to adapt the classical legal system to modern reality. Adopting Islamic law as 'a' or 'the' source of law in a constitution is part of a similar strategy. However, difficulties remain in trying to accommodate a divine law within a man-made legal framework, and in ensuring the translation of Islamic law from a jurists' law into positive law.

The reference to Islamic law in a constitution allows countries to keep working in a framework that recognises their identity as well as their historical, religious and cultural backgrounds. As stressed by Otto with regard to the new Iraqi and Afghan constitutions:

\footnotetext{
${ }^{22}$ S H Hashmi, Islamic Political Ethics: Civil Society, Pluralism and Conflict (2009) 159.

${ }^{23}$ M Abdelaal, 'Religious Constitutionalism in Egypt: a Case Study' (2013) 37(1) F Wld Aff 35, 37.
} 
The new governments of Afghanistan and Iraq desperately needed Shari'a to retain legitimacy in the eyes of their own people. After all the misery their countries had experienced, Islam was one of the few remaining forces that could foster a sense of unity and harmony. When Afghanistan and Iraq redefined themselves in the constitutions of 2004 and 2006, a prominent place was given to Islam. $^{24}$

This was specifically important in the case of Iraq where a neat demarcation from the secular government of Saddam Hussein was needed. In such circumstances, Islamic law becomes a symbol of attachment to a glorious Muslim past, and a sign of return to a history of continuity.

Including Islamic law in the constitution is also a way of framing the actions of a leader or a government: it creates a form of superior accountability. ${ }^{25}$ It limits the authority of the leaders by framing their temporal authority within divinely sanctioned bounds. ${ }^{26}$ Islamic law becomes the superior legal order to which human-made law has to refer, and by which it must abide. ${ }^{27}$ It is also a way of ensuring that there will be no violation of Islamic law by the leader. ${ }^{28}$

In this section, I have presented a few reasons why a country would choose to refer to Islamic law in a constitution. The discussion does not, however, ignore political arguments that these clauses are often the reflection of 'carefully negotiated provisions. ${ }^{29}$ The analysis in this section of the possible motives for including Islamic law in a constitution, and turning it into a source or the source of the law, demonstrates that there is an Islamically-informed constitutional model. This model is different from the one advocated by some transnationalist constitutional legal scholars. Instead, Islamic constitutionalism relies on a different definition of the role of the constitution and adheres to the model imagined by the Prophet, ${ }^{30}$ in which adherence to an Islamic principle of

${ }^{24}$ J M Otto, 'Rule of Law, Adat Law and Shari'a: 1901, 2001, and Monitoring the Next Phase' (2009) 1 HJRL 17.

${ }^{25} \mathrm{~N}$ J Brown, Constitutions in a Nonconstitutional World: Arab Basic Laws and the Prospects for Accountable Government (2001) 20.

${ }^{26}$ Ibid.

${ }^{27}$ Ibid.

${ }^{28}$ Feldman, above n 19, 122.

${ }^{29}$ Ibid.

${ }^{30}$ A An-Na'im, 'Religion, the State and Constitutionalism in Islamic and Comparative Perspectives' (2009) 57 Drake LR 829, 834. 
legitimate authority is a fundamental norm. ${ }^{31}$

\subsection{The Stakes of Including Islamic Law in a Constitution}

While different reasons exist for including Islamic law in a constitution, there are serious ramifications that arise from the adoption of a religious law as a/the source of law, especially in the context of human rights. The 1957 Constitution of Malaysia is an example of a legal document which establishes legal pluralism, prescribing different legal orders by community and subject matter, and in which Islamic law is a source of law. As a result, the Constitution supports a scheme for a dual system of Islamic law and secular law. A parallel system of courts exists, with Shari'a courts at the state level and secular courts at the federal level, the latter of which have the responsibility of protecting fundamental liberties. ${ }^{32}$ Article 3(1) of the Constitution states that 'Islam is the religion of the Federation; but other religions may be practiced in peace and harmony in any part of the Federation'. Article11 guarantees freedom of religion. Yet, there is debate regarding religious conversion in Malaysia: while conversion is not illegal, some provinces make it an offence on the basis of Islamic law. In five states (Perak, Malacca, Sabah, Terengganu and Pahang), converting from Islam is a criminal offense punished by a fine or a jail term. The state of Pahang punishes apostasy by six cane strikes. The state of Perlis has a rehabilitation year for all apostates before punishing them. The laws of those states are in clear contradiction with the human rights values set forth in the Malaysian Constitution. This tension has become even more visible recently. In the wake of Brunei's decision to implement Islamic criminal law, the Malaysian state of Penang declared its wish to have a stricter enforcement of that branch of law, arguing that the Constitution protects fundamental freedoms but allows for the existence of Islamic courts. The tension in Malaysia demonstrates the complexity of accommodating Islamic law into a federal and secular legal system.

This situation in Iran provides us with a clear insight into the role religion plays in a constitution in which Islamic law is the unique source of the law. Islamic law is at the core of the Constitution of the Islamic State of Iran and influences the entire legal and political system of the country. Religious law is the norm to refer to in order to enact appropriate laws and to prevent the enactment of laws which would negatively impact on the religion (or religious

\footnotetext{
${ }^{31}$ Asma Jilani v The Government of the Punjab PLD 1972 SC 139.

${ }^{32}$ J M Fernando, 'The Position of Islam in the Constitution in Malaysia' (2006) 37 JSAS 249.
} 
representatives). ${ }^{33}$ The whole aim of the Constitution is not only to establish the Islamic Republic, but to erect watchdogs which will ensure the protection of the Republic. The Guardian Council, set up by Article 91 of the Constitution, plays that role: it is a body made up of twelve experts, clerics and jurists, which checks the constitutionality and Islamicity of each bill presented to Parliament. When the Majles (Parliament) writes up a bill, it is sent to the Council as an instance of substantive control. The bill will then navigate between the two bodies before becoming a law. Different governments and Majles in Iran have undergone this process with several failures, mainly exemplified by the attempt to pass a bill on Convention on the Elimination of All Discrimination against Women (CEDAW) by the Khatami Administration. The political program of Mohammad Khatami, Iran's fifth President, rested mainly on the reform of the laws of the country within the existing constitutional framework, using the aforementioned new hermeneutics of the Sharia. ${ }^{34}$ He aimed at reforming the legislation by relying on new and modern interpretations of Islam. His purpose was to interpret the sources of law in a new light, in order to reform Iranian Islamic law to ensure compatibility with universal human rights without changing the Iranian constitution. ${ }^{35}$ Yet, he struggled with his reforms mainly because the Council of Guardians emptied most of the reformist Parliament's bills of their content. The bill which attempted to lead to a ratification of CEDAW is a striking example: when a group of MPs attempted to have CEDAW ratified in 2003, the Council revised the bill several times, changing its content until the bill was finally rejected on the grounds that it was un-Islamic. ${ }^{36}$ One of the arguments of the Council was that the Iranian constitution claims a relative equality between men and women in the Preamble, Article 3 and Article 20, and states in Article 21 that women's rights will be protected. These protections are Islamic. Yet, those in favour of the ratification of CEDAW argued that the new hermeneutics of the Shari'a would allow for some reform of Iranian Islamic law, allowing an opportunity to bridge the existing gap between Iranian law and universal human rights standards. ${ }^{37}$ Their aim was to empower women beyond Islam, therefore transcending the existing constitutional principles to provide for the universal

\footnotetext{
${ }^{33}$ Ahmed and Ginsburg, above n 3, 76.

${ }^{34}$ A Van Engeland, 'Bridging Civilizations: The New Hermeneutics of Islamic Law' in H Karim and M Eid (eds) Engaging the Other: Public Policy and the Clash of Ignorance (2014).

${ }^{35}$ M Khatami, Hope and Challenges: The Iranian President Speaks (1997).

${ }^{36}$ Z Mir-Hosseini, 'Fatemeh Haqiqatjoo and the Sixth Majles: A Woman in Her Own Right' (2004) 223 Middle East Report 34.

${ }^{37}$ Van Engeland, above n 34.
} 
protection of women's rights. Unfortunately, in this case, the practice of the new hermeneutics was barred by a constitutional mechanism. This phenomenon of a constitutional body defeating an attempt to protect the constitution while allowing for changes demonstrates that the watchdogs of the Islamic Republic of Iran can be quite radical. It also shows the limits of arguing for a new hermeneutics of the Shari'a when the whole constitutional structure is resistant to changes. The tension between human rights and Islamic law which riddles the Iranian Constitution becomes then an obstacle to any reform. ${ }^{38}$ It should, however, be stressed that there have been instances where the new hermeneutics has been successful in Iran. One example is the 2003 changes to child custody laws, allowing the mother to keep custody of both female and male children until the age of 2 years. ${ }^{39}$

The Malaysian and Iranian examples clearly demonstrate that having Islam at the core of the Constitution, whether as 'a' or 'the' source of law, will affect the legal system. In a federal state like Malaysia, the federal secular law finds a mighty competitor. It becomes difficult to uphold human rights principles stated in the constitution when a contradiction arises between secular law and religious law. The conflict between the values of the constitution and Islamic law become visible. In Iran, the entire system is designed to create and maintain the Islamic Republic and prevent reforms from occurring. While these two examples do not imply that including Islamic law will necessarily lead to negative consequences, they do illustrate the type of issues it can raise.

\subsection{Consequences for Universal Human Rights}

The focus on universal human rights standards as a yardstick in this article should not be seen as an illustration of support for the theories that posit an inherent conflict between Islamic law and universal human rights. The aim is instead to demonstrate that the inclusion of Islamic clauses in a constitution raises the question of how best to accommodate universal human rights law, a man-made law, and Islamic law, a divine law. There is no implicit statement that Islamic law naturally violates human rights: constitutions containing Islamic clauses tend to be rather human rights-heavy. ${ }^{40}$

\footnotetext{
${ }^{38}$ A Van Engeland, 'Human Rights and Strategies to avoid Fragmentation as a Threat to Peace: Iran as a case-study' (2011) 5 IJHRL 25.

${ }^{39}$ A Van Engeland, 'Iranian Women and Legal Pluralism: the Impact on Women's Rights' YIMEL (forthcoming).

${ }^{40}$ Ahmed and Ginsburg, above n 3.
} 
The recent constitutional events in Iraq, Afghanistan, and Egypt show that the inclusion of human rights is an important part of the constitutions, which makes it necessary to address exactly how Islamic law is reconciled with contemporary international human rights philosophy. In this article, I seek to build bridges between Islamic law and universal human rights by building on the work on An Na'im, Baderin and Sachedina. ${ }^{41}$ The premise is that, while there are differences between the two legal systems, a dialogue can emerge based on the values that Islamic law and universal standards both share. This methodology of working on commonalities complements the new hermeneutics of the Shari'a, which as explained above, seeks to develop a new corpus of interpretations of Islamic legal sources. The purpose of using the new hermeneutics is not only to find those commonalities, but also to develop new interpretations.

For example, freedom of expression exists in Islam. It is, however, conceived differently than in the Universal Declaration of Human Rights, and is limited by the respect for Shari'a. In Iran, this limitation also includes respect for persons representing religious authorities and Islam, such as the Guide. ${ }^{42}$ Concretely, this means that citizens can use their freedom of expression as long as they are not blasphemous or do not insult any religious authority or body. A reformed interpretation could support a less limited freedom of expression to encourage freedom of (and from) religion, as well as the freedom to disagree with religious authorities and bodies. The main issue then is how to reconcile the constitutional human rights values present in the majority of Muslim constitutions with an Islamic clause. This issue is directly addressed in the last part, in which I argue that we should step further away from classical understandings of Islamic law. ${ }^{43}$

If we wish to continue working within a nation state framework, it is firstly important to look at the consequences of the presence of Islamic law in the constitution. Beyond the textual intricacies of including Islamic law in the constitution, the effect of having a subjective source of Islamic law in the Constitution, in opposition to the objective approach of State law, can be antagonistic towards universal human rights, as illustrated by Iran and Malaysia.

\footnotetext{
${ }^{41}$ A A An Na'im, in A A An Na'im et al (eds), Human Rights and Religious Values: An Uneasy Relationship? (1995) 229-242; A Sachedina et al., Human Rights and the Conflict of Cultures: Western and Islamic Perspectives on Religious Liberty (1988).

42 The Guide is the main leader of the Islamic republic of Iran: he is the head of state alongside the President and is the highest religious authority.

${ }^{43}$ A A An Na'im, in A A An Na'im et al. (eds) Human Rights and Religious Values: An Uneasy Relationship? (1995) 229-242; A Sachedina et al., Human Rights and the Conflict of Cultures: Western and Islamic Perspectives on Religious Liberty (1988).
} 
Only three religions apart from Islam (Christianity, Zoroastrianism and the Jewish faith) are officially recognised by Article 13 of the Iranian Constitution. Citizens holding religious beliefs other than those mentioned in the constitution are ostracised. These three faiths are allowed to practice their religion, but cannot propagate it. While Catholics have been free to practice their faith, Protestants, despite Christianity being constitutionally accepted, have faced prosecution. The main issue religious minorities face within an Islamic republic where the entire system is Islamic is to be subjected to Islamic law. In Iran, Islamic jurisprudence is applied to non-Muslims, unless exceptions are created. In Malaysia and Nigeria, non-Muslims still have the opportunity to go to a secular court at a certain point in the procedure while in Iran, all courts are religious.

The Malay dual court system has affected human rights by creating a double standard in the application of the law. The problem has been furthered by the refusal of secular federal high courts to accept jurisdiction for apostasy cases, even in those cases essentially about fundamental liberties which falls under their jurisdiction. The Lina Joy case is probably the best illustration of the double standard. In this case, a woman who had converted to Christianity was refused a new ID card when she sought to marry a Christian man. ${ }^{44}$ Secular authorities indicated she had to go to a Shari'a court for it to issue a conversion order. She went to the secular courts to contest the policy which infringed on her constitutional freedom of religion as protected by Article 11 of the Malaysian Constitution. The High Court, ${ }^{45}$ and the Court of Appeal, ${ }^{46}$ stated that only an order issued by a Shari'a court could allow her to change her religion and therefore her ID card. Lina Joy then went to the Federal Court of Malaysia, the highest court and the court of last resort in Malaysia, which heard her case in 2007. The Court confirmed that only a Shari'a court could judge cases pertaining to religious conversion. ${ }^{47}$ The Court confirmed its previous decision in the 1999 Soon Singh case, in which it was stated that Article 121(1a) of the Constitution grants jurisdiction over religious matters to Shari'a courts. ${ }^{48}$ Since the Shari'a courts had jurisdiction over cases of conversion to Islam, it could be understood that they would also be competent for conversions from Islam. ${ }^{49}$

\footnotetext{
${ }^{44}$ Law Reform (Marriage and Divorce) Act 1976 (Malaysia).

${ }^{45}$ Lina Joy v Majlis Agama Islam Wilayah Persekutuan \& Anor [2004] 2 MLJ 119 [Malaysia].

${ }^{46}$ Lina Joy v Majlis Agama Islam Wilayah Persekutuan \& Anor [2005] 6 MLJ 193 (CA) [Malaysia].

${ }^{47}$ Lina Joy v Majlis Agama Islam Wilayah Persekutuan \& Anor [2007] 4 MLJ 585 (FC) [Malaysia].

${ }^{48}$ Soon Singh A/L Bikar Singh v. Pertubuhan Kebajikan Islam Malaysia (PERKIM) Kedah \& Anor (1999) 1 MLJ 489

${ }^{49}$ Soon Singh S/O Bikar Singh v Pertubuhan Kebajikan Islam Malaysia (PERKIM) Kedah \& Anor [1999]
} 
The Lina Joy case clearly illustrates how having a dual system of courts can limit the freedom of religion. The message of the secular Federal Court was that, in religious matters, Shari'a law supersedes the freedoms guaranteed by the constitution. ${ }^{50}$ This example demonstrates that using Islamic law as a source of constitutional law can be problematic when it comes to enforcing other values present in the constitution. The matter can be even more complex when Islamic law accommodates customary law or when Muslim customary law reclaims its role as a source of constitutional law. It is then important to consider how Islamic law as 'the' source of law deals with Muslim customary law in a dual basic norm system and how Islamic law as 'a' source of law, equal to customary law in the constitution, is affected by what Otto calls the 'triple basic norm', that is the presence of religious law and customary law in a Constitution. ${ }^{51}$ An example of a triple norm is Article 2 of the Iraqi Constitution. Such a triple norm exists when a constitution declares that Islamic law (norm 1) must respect customary law (norm 2) and universal human rights (norm 3). The triple norm can be reduced to a dual basic norm when customary law is excluded. The aim of the following discussion is to explore the role of Islamic law and Muslim customary law in the development of constitutions, but also to appreciate how this triple basic norm (Islamic law, customary law and human rights), or the dual basic norm (Islamic law and human rights), once constitutionalised, functions and what must be done when a conflict of laws emerges.

\section{Considering Customary Law when Developing a Constitution}

Eugen Ehrlich was correct in arguing for jurisprudents to take the 'living law' into account when considering positive law, encompassing usage and custom. However, it is important to address the issues arising from legal pluralism. ${ }^{52}$ In an Islamic environment, the inclusion and exclusion alike of customary law in the constitution hold consequences for the application of Islamic law and for human rights. Before engaging with these tensions, however, it is necessary to understand the motives for including Muslim customary law when developing a

\footnotetext{
1 MLJ 489 [Malaysia].

${ }^{50}$ M Kirby, 'Fundamental Human Rights and Religious Apostasy: the Malaysian Case of Lina Joy' (2008) 17(1) Griffith LR 151.

${ }^{51}$ Otto, above n 24, 15.

${ }^{52}$ E Erhlich, Fundamental Principles of the Sociology of Law (1937).
} 
constitution. For the purpose of this article, Muslim customary law is defined as the social rules perceived by Muslims as being norms derived from Islamic law, even though these norms are not translated into either (official) Islamic or state law.

\subsection{Motives for Including Customary Law in a Constitution}

Imposing positive law without taking into account the existence of a variety of local sources such as religion and customary law can make a constitution fail in its mission to represent the political community or 'people'. As stressed by An Na'im, a constitution which considers cultural and religious values is more likely to be internalised and enforced by the community. ${ }^{53}$ The factor of 'cultural legitimacy' encourages citizens to abide by State law, even though their mode of life might not be the one of a nation-sate. ${ }^{54}$ The above analysis on the inclusion of Islamic law in constitutions has demonstrated a similar trend: a constitution, to be accepted, needs to reflect not only the needs and expectations of people (for example with regard to human rights) but also the cultural, traditional and religious values of a people as a self-perceived political community. The extent to which the latter needs to be included is dealt with in the last part of this paper.

In many Muslim countries, customary law is a reality and various constitutional texts have acknowledged that situation. Pluralism is an empirical reality, and most legal systems in the Muslim world are constructed with the awareness that to maintain social peace and ensure uniformity of law enforcement throughout the country, other sources of law must be taken into consideration. Muslim customary law then becomes a source of the law. One of the reasons why drafters of constitutions in the Muslim world choose to integrate this 'living law' is to encourage a pluralist system which reflects the identity of the population. ${ }^{55}$

Including Muslim customary law is also a way of ensuring the survival of practices and alternative approaches to the law which can sometimes be an enrichment to the legal system. Another reason for including customary law is to ensure that positive law does not oppress indigenous populations. ${ }^{56}$ The denial of local culture and systems of laws can be destructive for a community. Menski

\footnotetext{
${ }^{53}$ A A An-Na'im, African Constitutionalism and the Role of Islam (2006) 99.

${ }^{54}$ A A An Na'im, in A A An-Na'im and F M Deng (eds), Human Rights in Africa: Cross-Cultural Perspectives (1990) 331-367.

${ }^{55}$ M Ndulo, 'African Customary Law, Customs, and Women's Rights' (2011) 18 Ind J Global Legal Stud 87, 94.

${ }^{56}$ W Menski, 425
} 
refers to the African literature on the matter of 'broken heritage' to illustrate this point. ${ }^{57}$ During colonisation, many local communities suffered from the lack of consideration of their rules, resulting from Western legal transplants and were impacted by attempts to regulate and control their beliefs, leading to the feeling that the denial or transformation of local customary law could break or destroy a heritage. Including customary law as a source of law is therefore a way of acknowledging the importance of the community's culture.

A customary law-inclusive constitution also avoids 'self-controlling systems, ${ }^{58}$ in which individuals or particular groups might be at risk of discrimination. ${ }^{59}$ The existence of parallel legal systems can be perceived as competing with the State and this is why it might be necessary to control customary law via the constitution and State law, and why some States have felt the need to 'domesticate' customary law. ${ }^{60}$ A balance needs to be found, however, between upholding State law and the need for communities to develop their own laws. Framing the scope of 'self-government' within the constitution is therefore vital for the nation state. ${ }^{61}$ This provides powerful reasons for both religious law and customary law to be developed in accordance with the general philosophy of the constitution.

There are also constitutions in which a conscious choice has been made not to include customary law (Iran, Mauritania, the Maldives), while others are unclear about whether or not customary law is a source of law (Afghanistan, Iraq). The deliberate choice to exclude is usually based on the perception that pluralism creates a risk of fragmentation, which would then undermine the Islamic 'supremacy-clause model' constitution. The lack of clarity in a constitution with regard to the role of customary law as a legal source can, however, cause problems and even undermine the State's authority. This is demonstrated below, in the examination the case of Afghanistan.

\subsection{The Stakes of Including and Excluding Muslim Customary Law}

The inclusion or exclusion of Muslim customary law in a constitution leads to different consequences, as illustrated in Nigeria and Afghanistan. The 1999

\footnotetext{
${ }^{57}$ Hirschl, above n 15, 191.

58 Ibid, 421.

${ }^{59}$ F Banda and C Chinkin, Gender, Minorities and Indigenous People (2004) <http://www.unngls.org/orf/cso/cso6/MRGGenderReport.pdf> [accessed 25 May 2014].

${ }^{60}$ Hirschl, above n 15, 191.

${ }^{61}$ H P Glenn, Legal Traditions of the World: Sustainable Diversity in Law (4 ${ }^{\text {th }}$ edn, 2010) 92.
} 
Constitution of the Federal Republic of Nigeria sets up a federal system in which emphasis is put on the 'spirit of mutual coexistence ${ }^{, 62}$ between the various national communities. In practice, any received English law has to co-exist with Islamic law and different forms of customary law, including Muslim customary law, in different parts of the country. While Section 10 of the Constitution rejects the promotion of a State religion, the federal system has allowed for the existence of state courts to consider matters not covered by federal law, as per Section 6(5) and Sections 275-279 of the Constitution. These articles have been used to legitimate the recourse to Islamic law and Muslim customary law. For example, in some areas of the country, marriage is partly regulated by Muslim customary law. Yusuf speaks of the right of a father to remove a child from a divorced woman after the cut-off age of 2 years old, rather than puberty. ${ }^{63}$ The rule is a departure from the Maliki school of Islamic jurisprudence, the predominant school of law in Nigeria, which states that the female child remains with the mother until marriage and the male child until he reaches maturity. This could potentially create a conflict of laws between Islamic law and customary law. The enforcement of stoning is another issue stemming from Muslim customary law in Nigeria: it is sometimes used as a punishment by Shari'a courts. It is clear that stoning is not to be found in Islamic law and is a pre-Islamic customary practice which has found its way into some Muslim customary law and sometimes into State courts and State law stating an Islamic basis. ${ }^{64}$ There is certainly debate regarding the conflation of Muslim customary law and Islamic law. It is sometimes difficult to make the distinction between Muslim customary law and Islamic law, as reflected in the case law of Shari'a courts in the Northern parts on Nigeria. ${ }^{65}$ Islamic law and Muslim customary law can be perceived as intrinsically linked. ${ }^{66}$ The outcome of this congruence is that in some regions, Shari'a courts will apply customary law in the light of Islamic law while in other areas Muslims who have contracted an Islamic marriage will have to go to a customary court. ${ }^{67}$

The Constitution of Afghanistan is an example of a constitution which does

\footnotetext{
$\overline{{ }^{62}}$ H P Glenn, Legal Traditions of the World: Sustainable Diversity in Law $\left(4^{\text {th }}\right.$ edn, 2010) 92.

${ }^{63}$ M A Yusuf, 'Impact of Local Government Reforms on Yauri Division' (1973) PhD thesis, Ahmadu Bello, as cited by F A Salamone, 'The Clash between Indigenous, Islamic and Post-Colonial Law in Nigeria' (1983) $21 J L P$ 15, 31.

${ }^{64} \mathrm{C}$ Jones-Pauly, 'Law: Articulation of Islamic and non-Islamic Systems' in S Joseph (ed), Encyclopedia of Women and Islamic Cultures: Family, Law and Politics (2005) 387.

${ }^{65}$ A A Oba, 'Religious and Customary Laws in Nigeria' (2011) 25 Emory Int LR 881

${ }^{66}$ Ibid, 885.

${ }^{67}$ A A Oba, 'The Sharia Court of Appeal in Northern Nigeria: The Continuing Crises of Jurisdiction' (2004) 52 Am J Comp L 859, 882.
} 
not clearly refer to customary law as a source of law. While there is a reference to the beliefs of Islam in Article 3 of the Constitution, customary law is not directly identified as a source of law. Yet, it is a source de facto and the lack of clear acknowledgment of its role has been seen to undermine State authority. ${ }^{68}$ Indeed, the unofficial, unwritten parallel legal system based on customary law leads to many human rights violations, ${ }^{69}$ in the different local councils and even in local courts. Many Afghan judges prefer to apply customary law, or are unaware of the relevant State law. While the reasons for ignoring the role of customary law in enacting a constitution can be multiple, one emerges clearly: the fear of granting legitimacy to a potential competitor to State law, especially in a post-conflict setting. However, by ignoring the contribution of customary law, countries which have chosen to rely on Islamic law in their constitution expose themselves to internal contestation, as it is the case in Iran where different ethnic groups would like to rely on their own belief systems. It also dis-empowers the State when it comes to preventing discrimination, as some customary rules can affect gender and vulnerable groups negatively.

Nowadays, the application of Muslim customary law is explained by different factors: the political context; popular support; a lack of engagement with the State legal system; and ethnic motives. ${ }^{70}$

\subsection{Consequences for Human Rights}

The consequences of including customary law in the constitution are just as problematic as the exclusion of customary law. Informal parallel justice systems which enforce Muslim customary law are a major obstacle to the respect of human rights. It would be a mistake, however, to believe that all customary rules will be discriminatory or violate fundamental rights. Yet, one must acknowledge that Muslim customary law, just as Islamic law, is a subjective source of law, as opposed to objective State law. Interpretations of Islamic legal sources and social pressure place weight on Muslim customary law as well as in Islamic law, and define their content. When Shari'a inspires customary law and when Islamic law inspires law, it is done in a way that reflects a social and cultural identity and a

\footnotetext{
${ }^{68}$ K Reedy, 'Customary law and its Challenges to Afghan Statehood'(2012) Mil Rev 27.

${ }^{69} \mathrm{M}$ Lau, 'Afghanistan's Legal System and its Compatibility with International Human Rights Standards' International Commission of Jurists (2003) <http://www.refworld.org/pdfid/48a3f02c0.pdf> [accessed 25 May 2014].

${ }^{70} \mathrm{M}$ Lau, 'Afghanistan's Legal System and its Compatibility with International Human Rights Standards' International Commission of Jurists (2003) <http://www.refworld.org/pdfid/48a3f02c0.pdf> [accessed 25 May 2014].
} 
purpose. This is in contradiction with State law in a nation state which claims to remain as objective as possible. ${ }^{71}$

Interpretation and social pressure can have negative effects on human rights as illustrated by the honour murders in Syria. While the Syrian Constitution establishes gender equality, a number of women are still killed for dishonouring their family and their community. This is in retribution for their behaviour deemed to be inappropriate, which can range from talking a male who is not a member of the family to refusing to marry. ${ }^{72}$ In parts of Syria, it is believed that the shame should be washed away, and for some people, this can only be achieved by blood. ${ }^{73}$ This is an ancient tribal custom which, over time, has been given a societal seal of approval, although it is in contradiction with certain textual elements of Shari'a and Islamic law. A noted case is that of Zahra al-Azzo, who was killed in her sleep by her brother. ${ }^{74}$ This case demonstrates that customary law can violate internationally accepted universal human rights. It also demonstrates that on some occasions, State laws and State courts can support customary law; Article 192 of the Syrian Penal Code provides that the judge may excuse or reduce the punishment of a person who commits 'a crime under honour'. Article 548.1 of the Code states:

Anyone who catches his wife, one of his female ascendants or descendants, or his sister committing adultery or engaging in illegitimate sexual relations with another person and who, without intending to do so, murders, beats or injures his relative and her accomplice, is exempt from punishment.'

Syrian courts have applied these articles, including in Zahra's case, to excuse the murderer. These rules directly contradict Article 45 of the Syrian Constitution, which affirms equal citizenship. Women are said to enjoy the same social status as men, but old practices and hard-line interpretations have led to toleration of honour killings as part of the local culture.

\footnotetext{
${ }^{71}$ Kelsen, above n 55, 405.

${ }^{72}$ L Abu Odeh, 'Honor Killings and the Construction of Gender in Arab Societies' in M Yamani (ed), Feminism and Islam: Legal and Literary Perspectives (1996) 141-194.

${ }^{73}$ A Van Engeland, 'On the Path to Equal Citizenship and Gender Equality: Political, Judicial and Legal Empowerment of Muslim Women' in LC McClain and J L Grossman (eds), Gender Equality: Dimensions of Women Equal Citizenship (2012) 390-408.

${ }^{74}$ Zahra was abducted and raped before her marriage by a family friend. Later, a cousin proposed to her, despite this incident, and she got married. Her brother still believed it was necessary to 'wash away the shame' (ghasalat al arr) by killing her. See K Zoepf, 'A Dishonorable Affairs' NY Times, 23 September 2007.
} 
The acknowledgment of legal pluralism in a constitution is important to uphold social peace and protect local sources of law. Excluding religious and customary sources of law seldom works to the advantage of any society, as illustrated by the numerous examples above. However, it must be acknowledged that some religious and religiously-inspired customary laws are in direct antagonism to universal human rights. To be framed properly in a nation state constitutional era, Islamic law and Muslim customary law need to undergo changes. That is to say, to co-exist with state law and universal human rights law in a pluralist constitutional system, both Islamic law and Muslim customary law must move yet further away from classical readings of Islam and Islamic law.

\section{Islamic Law versus Customary Law: Tensions and Impact on the Constitution and Human Rights}

There are sometimes clear discrepancies between Muslim customary law and Islamic law. They can affect the general philosophy of the constitution, as illustrated in Afghanistan. These conflicts emerge when Islamic law is the main source of law in a constitution that also considers customary law, which in turns contradicts Islamic law. Conflicts can also occur when Islamic law does not tolerate any competitor and excludes Muslim customary law.

The first step is to differentiate Islamic law from Muslim customary law. While many scholars conflate them, the two sources of law are of different origins and purposes. Islamic law is a divine law which seeks to respect the word of God in a man-made context. Customary law is 'the body of rules which are recognised as obligatory, ${ }^{, 75}$ and is designed by and for the community. So, one law is divine while the other is organic. To place them in the context of a nation state's constitution means working within Otto's triple basic norm (or dual norm) and finding solutions to potential conflicts of laws.

\subsection{Tensions between Sources}

One cannot ignore the fact that the citizen will often find himself caught between the dual basic norm (Islamic law versus Muslim customary law) or the triple basic norm (Islamic law, Muslim customary law, and human rights) with the potential

75 T O Elias, The Nature of African Customary Law (1972) 55. 
for a double violation of human rights: one can be victimised once by Islamic law and another time by customary law, or by both when they are in conflict. As an illustration, in Afghanistan, a woman can be the victim of an interpretation made of Islamic legal sources that forces her to marry and she can then be the victim of a customary rule that compel her to remain inside at all times. Both Islamic law and Muslim customary law can only remain as constitutional sources of the law in a constitution that enshrines universal human rights if both undergo an in-depth reform.

Before looking at a methodology for reform, it is important to understand the nature of the conflict of laws which emerges. The co-existence of Islamic law and Muslim customary law or the de facto implementation of customary law can lead to conflict between the two types of law. In a country which stipulates Islamic law as the source of the law, there is no other competitor and Islamic law controls the legal system. This is the case in Iran where Islamic law is the only source of the law and where customary law is ignored. ${ }^{76}$ This causes significant tensions with the different ethnic groups in Iran. In contrast, there is a plurality of sources of law in Afghanistan which has caused conflicts, consequently undermining the State's authority. While several parts of the country are difficult to access in order to ensure the rule of law, there is no legal vacuum as Muslim customary law is applied in these places. ${ }^{77}$ As a result, Afghan law is a mix of international law (Article 57 of the Constitution), Statutory law (which is a mix of civil and Islamic law), Islamic Hanafi law (Article 130 of the Constitution) and, de facto Muslim customary law. There are areas where local judges and local councils apply customary law rather than domestic law. For example, there is a clash of norms between the Islamic law and the customary law on the matter of inheritance. The Pashtu customary law states that women do not have the right to inherit. Islamic law, on the other hand, considers that women have a share of the inheritance. ${ }^{78}$ Another illustration is provided by Welchman's analysis of competing legal systems in the Palestinian Occupied Territories, wherein she considers case studies and analyses how the three bodies of law interact. ${ }^{79}$ A last example of a conflictual enforcement of Islamic law and Muslim customary law

\footnotetext{
${ }^{76} \mathrm{Z}$ Nejadbahram, 'Women and Employment' in T Povey and E Rostami (eds) Women, Power and Politics in 21st Century Iran (2012), 73, 80; Hadi Enayat, Law, State, and Society in Modern Iran: Constitutionalism, Autocracy, and Legal Reforms (2013), 28.

${ }^{77}$ A Wardak, 'Jirga: a Traditional Mechanism of Conflict Resolution in Afghanistan' (2003) $<$ http://unpan1.un.org/intradoc/groups/public/documents/apcity/unpan017434.pdf> [accessed 25 May 2014].

${ }^{78}$ A J Arberry, The Koran Interpreted (1963).

${ }^{79}$ L Welchman, 'The Bedouin Judge, the Mufti, and the Chief Islamic Justice: Competing Legal
} 
can be found in Darfur, as demonstrated by Unruh who analyses how Islamic land law conflicts with customary law. ${ }^{80}$

In another example, a woman saw her husband leave to join the Taliban in Afghanistan. ${ }^{81}$ When he did not return from the war after 9 years, the village council allowed the woman to re-marry, considering the husband had deserted her. She re-married and had 2 children. The first husband returned, and the woman was accused by the very same village council of committing adultery (zina), on the basis of Hanafi law which states that a woman is considered divorced after 99 years have passed since the birth of the husband. The move from case law to classic Hanafi law was justified on the customary rule that a woman needs to protect her honour. The woman consequently had to flee to ensure her survival, as the village council intended to stone her in accordance to customary law. This area of the law is highly contentious, but there is a judicial agreement that Hanafi law is too stringent and Afghan courts have instead relied on Maliki law which sets the cut-off period of waiting at 4 years. ${ }^{82}$ Yet, the council at hand had changed its initial decision which was in line with domestic case law to switch back to a mix of classic Hanafi law and customary law.

It is interesting to note that scholars have attempted to reconcile different sources of law at the time of colonisation, with varying degrees of success. There is much to learn from their experience, from their misunderstandings of local laws and from their analysis of the interactions between State law and other legal systems. The Dutch scholar Van Vollenhoven analysed the role of local customs (adat) in what used to be the Netherlands East Indies (Indonesia), and concluded that it was a legal system in itself. He called it adatrecht, the law of the customs. In his mind, Islamic law was absorbed by this adatrecht, and therefore approached by Vollenhoven as being an inherent part of customary law, ${ }^{83}$ which demonstrates a misunderstanding of the concept of Sharia. The French had a different approach in Algeria, which was to transplant their legal instruments and codify Islamic law. Customary law was then considered as a 'deformation' of Islamic law. ${ }^{84}$ It should be noted that the codification of Islamic

Regimes in the Occupied Palestinian Territories' (2009) 38 JPS 6.

${ }^{80}$ J D Unruh, 'Land and Legality in the Darfur Conflict' (2012) 5 African Security 105.

${ }^{81} \mathrm{~J}$ D Unruh, 'Land and Legality in the Darfur Conflict' (2012) 5 African Security 105.

${ }^{82}$ M H Kamali, Law in Afghanistan: A Study of the Constitutions, Matrimonial Law and the Judiciary (1985) 187-9.

${ }^{83}$ W R Roff, 'Customary Law, Islamic Law and Colonial Authority: Three Contrasting Case Studies and their Aftermath' (2010) 49 Islamic Studies 455, 457.

${ }^{84}$ W R Roff, 'Customary Law, Islamic Law and Colonial Authority: Three Contrasting Case Studies and their Aftermath' (2010) 49 Islamic Studies 455, 457. 
law did not prevent the practice of customary law, ${ }^{85}$ a situation reminiscent of Afghanistan today. The last example is Roff's example of British India, where an Anglo-Muhammadan law was created. The British compiled customary laws by district to ensure the application of a uniform customary law. ${ }^{86}$ When Islamic law and customary law conflicted, customary law would supersede Islamic law on the basis that Anglo-Muhammadan law would be applied unless 'the law has been modified by custom. ${ }^{87}$ We can conclude that since conflicts of laws already existed before the time of colonization, the addition of an extra layer of law, State law, led to legal pluralism as an obvious choice for India's post-colonial constitution. These conflicts of laws affect citizens and need to be resolved in a manner which protects both the constitution and the nation state. This will be illustrated below.

\subsection{Addressing Issues that arise when Including Islamic Law and Muslim Customary law in Constitutions}

A constitution should not be developed ex nihilo and should consider the historical, social and cultural context as well as other sources of law of the country. ${ }^{88}$ Legal pluralism facilitates the development of a constitution by considering cultural, traditional, customary and religious values. ${ }^{89}$ It should be stressed that Griffiths disagrees with the attempt to have legal pluralism and State positivism work together:

[F]ormal acquiescence by the State in a situation of legal pluralism in this weak sense adds a formidable layer of doctrinal complexity on top of complexity normally incident to a supposedly uniform state legal system. The resulting state of affairs is regarded by almost everyone concerned as profoundly defective. It is the messy compromise which the ideology of legal pluralism feels itself obliged to make with recalcitrant social reality. ${ }^{90}$

\footnotetext{
${ }^{85} \mathrm{~J}$ R Henry and F Balique, La Doctrine Coloniale du Droit Musulman Algérien: Bibliographie Systématique et Introduction Critique (1979) in Roff, above n 84, 458.

${ }^{86}$ Ibid, 460.

${ }^{87}$ Ibid, 460.

${ }^{88} \mathrm{~J}$ W Burgess, Political Science and Comparative Constitutional Law (1983) 90.

${ }^{89}$ An Na'im, above n 53, 99.

${ }^{90}$ Griffith, above n 14, 7.
} 
Griffiths seeks to tackle this complexity by demonstrating that Islamic law, as a unique 'normative phenomenon," can absorb both legal pluralism and State positivism due to its flexible nature, and that religious law becomes State law on incorporation in the constitutional text. But if this is the way forward, a yardstick has to be set as to which of those values are acceptable, especially with regard to the respect and enforcement of universal human rights law. This yardstick can be found in Islam itself, which provides the relevant tools to make a distinction between the acceptable and the non-acceptable. While interpreting Islamic legal sources to create law and customary law, one can use Islamic instruments which can then serve as yardsticks. These instruments include, for example, maslaha which is the public good, or darura which means necessity, amongst other Islamic legal principles. Both of these principles are instruments used in Islamic law to either contextualise Islam or interpret Islamic legal sources. Interpreting legal sources while relying on these tools can help us find a solution for the above-mentioned problem of punishment for adultery (zina); instead of attempting to re-interpret the Quran when it comes to the punishment of adultery (an impossible move since the Quran is the word of God and is not fallible), one can extend the new hermeneutics of the Shari'a to the inclusion of maslaha (public interest). It could be argued that the punishment of adultery by strikes should be prohibited on the basis that it does not serve the public interest. The punishment prescribed in the Quran is then mitigated in its enforcement by the principle of maslaha: it is not in the public interest or for the well-being of the community to enforce such harsh punishments. Sharia law will in turn be transformed by the reforms operated within Islamic law and Islam, influencing customary law in a positive way. It is crucial to determine whether maslaha and other Islamic legal principles constitute a new normative order or not: while it is clear that they do not constitute norms by themselves, there is a debate as to whether they are principles of law or sources of law. As principles, maslaha and darura (and other such interpretive devices) could be used to contextualise interpretations of the Quran and the Sunna. The public good (maslaha) would then become the general context in which one interprets Islamic legal sources. If maslaha, or any other Islamic legal instrument, is considered as a source of law, we then begin shaping a new normative order. The aim of that new normative order is to ensure a swift conciliation with universal human rights law. Yet, it creates the risk of departing from the very nature of Islamic law by turning elements which are meant to be principles into sources of law (i.e. rules). These principles

${ }^{91}$ Twining, above $\mathrm{n} 13,116$. 
are there to serve as yardstick, and not as norms. Islamic principles should play a role in the evolution of Islamic law and Muslim customary law in order to create new opportunities for interpretation. These new interpretations could build bridges with universal human rights while upholding the Islamic identity of a constitution. Changing the nature of Islamic law, or its order of legal sources, should not be a strategy. Rather, by encouraging a new hermeneutics of Islamic law and Muslim customary law, we actually promote new values which will be closer to those reflected in human rights standards. This would allow us to work on the real issue, which is interpretation.As stressed by An Na'im, ${ }^{92}$ the issue is not with Islam and Islamic law but with the way we interpret Islamic legal sources and understand them. The next step is to decide on the direction of the hermeneutics. The different principles in existence, such as maslaha, serve as yardsticks, acting as a baseline from which differences between interpretations of Islamic law and universal human rights can be reconciled in a hermeneutic process.

With a methodology and a yardstick determined, a test needs to be established with regard to the selection of acceptable norms. The experience with regard to customary law in some African countries is enlightening. In Nigeria, a customary rule is tested through a repugnancy clause to ensure that a rule is socially acceptable. A test of compatibility with statute law is then performed, followed by a test of compatibility with public policy.94 This example would call for similar tests with regard to Islamic law and Muslim customary rules. There is a precedent of such a test being applied in Ghana, where the State applies a Muslim customary law to change inheritance law with a gender focus. ${ }^{93}$

\subsection{The Necessary Framework to Enforce Changes}

that The argument is that such reforms of Islamic law and Muslim customary law are only possible within a strong nation state. Indeed, Islamic law and customary law are, as stressed by Sultany, subjective sources of law which are prone to manipulation. This is why only a strong nation state can address issues of enforcement of both sources of law within a constitutional framework. This also entails that States actually comprehend the nature of their own legal sources and are able to adopt them successfully within a nation-state framework. A strong critic of this stance is Hallaq, who believes that the modern nation state cannot accommodate Islamic law as some inherent inconsistencies, such as

\footnotetext{
92 Ibid, 99.

${ }^{93}$ Ibid, 53.
} 
the codification of Islamic law, will inevitably arise. ${ }^{94}$ He refers to the Islamic Republic of Iran, which he perceives to have failed 'both Islamic governance and the modern state as political objects. ${ }^{\text {.95 }}$ He also denounces the restructuring of Shari'a law at the hands of the State, to this extent disapproving the suggestion made in this article to use a new hermeneutics of the Shari'a to transform the law. While Sultany's fear of manipulations and Hallaq's suspicions with regard to the capacity of modern nation State to cope with Islamic law's nature are well grounded, the new hermeneutics coupled with the use of Islamic principles such as maslaha does in fact allow for Islam to exist within the apparatus and structure of the modern state given the correct interpretative approach is applied. These new interpretations can solve the tensions between customary law, Islamic law and human rights (both domestic and universal), as the focus is set on conciliation.

The State has positive obligations towards human rights and towards its citizens. ${ }^{96}$ The need to have a strong State concerns all three branches of power in a government. In Afghanistan, for example, only an accelerated judicial reform controlled by the State and an in-depth judicial review performed by trained judges will ensure conformity, not with classical Islamic law, but with a newly reformed Islamic law. The outcome of this argument is that it is necessary to take Islamic law through a new period of reform, similar to the one the Ottomans led. To acheive this purpose, it is necessary to take yet another step away from classical Islamic law. Conformity with classical doctrine cannot be upheld in a nation state and Islam cannot be a fundamental norm outside of that modern constitutional context. Once this is established, boundaries to the power of executive, the judiciary and the parliament should be well-defined as these bodies will dictate the content of the laws (Islamic law) and the role of Muslim customary law.

As emphasised by Rabb:

The central question that Islamic constitutionalism evokes in the context of law-making and adjudication concern how to interpret Islamic legal texts within the particular governmental arrangement outlined by the constitution and executed by institutional actors. ${ }^{97}$

The enforcement of the yardstick developed above can be performed when drafting laws or making judgments. The main obstacle then becomes classical

\footnotetext{
${ }^{94}$ W B Hallaq, The Impossible State: Islam, Politics and Modernity's Moral Predicament (2012) x.

${ }^{95}$ Ibid, 2.

${ }^{96}$ Nmehielle, above n 70, 754.

${ }^{97}$ I A Rabb, “We the Jurists”: Islamic constitutionalism in Iraq' (2008) 10 U Pa. J. Const. L 527.
} 
Islamic law. The Egyptian Supreme Court has, for example, declared that some classical principles of Islamic law could not be altered, with regard to child custody and the cut-off age. ${ }^{98}$ Yet, the key is to move away from classical Islamic law and the idea that areas of Islamic law and Islam exist which cannot be changed. This move from classical Islamic law has already occurred to a certain extent. The author suggests that if we wish to maintain Islamic law and Muslim customary law within a constitutional framework and if we wish to keep them as sources in a nation state, we must move away from an approach to constitutionalism which takes classical Islam as the fundamental norm to develop instead a rights-based constitutionalism via ijtihad. However, we should not ignore that relying on State courts could be problematic. It has been reported that the court's intervention in Muslim customary law has a tendency to influence the rule with a view to homogenise it without actually reflecting its real content. ${ }^{99}$ Another issue is the training of the judges which often fall back on classical interpretations of Islamic law and customary law due to a lack of knowledge. As reported by Lau, Weinbaum had stressed this issue by stating 'where formal statutes exist, judges typically lack the training and research resources required to identify appropriate provisions of the law. ${ }^{100}$ While this view was expressed in 1980, the issue is still in existence nowadays.

The innovative proposed methodology will also defeat the argument that referring to religion in a constitution leads to the establishment of theocracy which in turn turns into despotism ${ }^{101}$ or the argument that customary law is oppressive of human rights. Instead, a new version of Islamic law and customary law will be promoted, once that completes the already existing positive values in these legal systems. It could create an all-encompassing revised legal pluralism which is more adapted to the $21^{\text {st }}$ century mode of governance and perceptions of the role of a constitution. However, this strategy will not allow us to move away from the criticisms that religion and customary law constitute subjective sources of law, prone to manipulation. The new hermeneutics of the Sharia is itself a form of manipulation of the sources, principles and methods in existence within Islam. This weakness should be acknowledged. It could be counter-balanced by the fact that there would no further need for a controlling authority outside of

\footnotetext{
${ }^{98}$ Abdelaal, above n 23, 39.

${ }^{99}$ E S Nwauche, "The Constitutional Challenge of the Integration and Interaction of Customary and the Received English Common Law in Nigeria and Ghana', (2010) Tulane Eur \& Civ L Forum $25,37-63,43-44$.

${ }^{100} \mathrm{Lau}$, above $\mathrm{n} 73$.

${ }^{101}$ As rejected by Backer, above n 4, 104.
} 
the religious realm, since changes would come from religion itself and would be monitored by the three branches of power. ${ }^{102}$ The new hermeneutics of the Shari'a would also be a very slow process to develop as each rule would have to be addressed at a time. Besides, addressing the idea that 'religion divides and does not compromise. It tolerates but cannot accept equality among those of different faiths ${ }^{103}$ would entail a reform of the way other religions are perceived in Islam. As stressed by Baderin 'pluralism is considered as conflicting with constitutionalism on grounds that it can be internally segregate and thus impeded on the ideals of constitutionalism and possibly hinder good governance and social cohesion under a uniform system of law'. This concern would then have to be addressed using interpretation (ijtihad), being aware of the length of the reform.

This work demonstrates that far from constituting a threat to transnational constitutionalism, and far from that idea that 'the point is to subordinate these differences within the matrix of superior normative values represented within transnational constitutionalism, so that the populations of states that seek to politicize their religion will do so only in a manner that retains the superiority of secular values, ${ }^{104}$ Islamic law and Muslim customary law can develop in a new direction. Rabb has addressed all these fears and the use of the new hermeneutics to counter such argument that secularism is the only viable option in the field of religion and constitution. 105 The author furthers that mitigating Islamic law and customary law via secularism would cause the imposition of a foreign model, when Islamic instruments are available as an alternative. An Islamic-based reformed constitutionalism could also construe its own perceptions of universal human rights in a way that leads to bridging the different legal systems to later embracing universal rights.

\section{Conclusion}

"We the people" is an important part of any constitution, and also happens to be at the very core of Islam: Shari'a is guiding Muslim believers in all aspects of their lives, including the law. The main difference is that in some Muslim constitutions, the people are represented via religion and/or Muslim customary law. It is undeniable that the presence of both Islamic law in and customary

\footnotetext{
${ }^{102}$ Ibid.

${ }^{103}$ Backer, above n 1, 37.

${ }^{104}$ Hirschl, above n 4, 1181.

${ }^{105} \mathrm{Rabb}$, above $\mathrm{n} 101$.
} 
law in a constitution raises issues, especially with regard to the respect and enforcement of universal human rights. It is also true that their presence is necessary as it reflects the will of the people. Sultany questions this understanding of a constitution, asking whether we know what the people want; whether a constitution should or should not reflect an identity; whether interpretation does not lead to indeterminacy; and whether the dominance of Islam does not lead to a 'dominance of the religious divide, an anti-democratic form of secular escapism and depolitisation of essentially political questions. ${ }^{106}$ The author believes, in response to the two first concerns, that legal pluralism is a necessity in any legal system which seeks to be legitimate, a point which was well-understood during the drafting of the new Iraqi and Afghan constitutions. Islam is by nature subjective and subject to interpretation due to its flexibility: the author perceives that element has positive and we should take advantage of it. Eventually, relying on Islamic law and Shari'a-influenced customary law is a way of relying on a local identity and avoiding the transplantation of yet another model of law. Indeterminacy remains a real issue caused by the very nature of Islamic law, a flexibility which also allows for reform: while this technique of the new hermeneutics is successful most of the time, issues remain. ${ }^{107}$ For example, the Shari'a punishment for adultery, zina, is clearly prescribed in the Quran 24:2.108 While the punishment prescribed, flogging, is in clear contradiction with human rights, ${ }^{109}$ a verse of the Quran cannot in itself be re-interpreted. The new hermeneutics focuses only on the human understanding of divine law, and not on divine law itself. The methodology of the new hermeneutics consequently encounters limits in terms of adapting Islamic law to the $21^{\text {st }}$ century demands.

\footnotetext{
${ }^{106}$ Sultany, above $\mathrm{n} 11$.

${ }^{107}$ A Van Engeland, 'Transcending the Human Rights Debate: Iranian Intellectuals' Contemporary Discourses and the New Hermeneutics of the Sharia' (2011) 4(1) MEJCC 72.

${ }^{108 ، T h e ~[u n m a r r i e d] ~ w o m a n ~ o r ~[u n m a r r i e d] ~ m a n ~ f o u n d ~ g u i l t y ~ o f ~ s e x u a l ~ i n t e r c o u r s e ~-~ l a s h ~ e a c h ~ o n e ~}$ of them with a hundred lashes, and do not be taken by pity for them in the religion of Allah, if you should believe in Allah and the Last Day. And let a group of the believers witness their punishment.'

${ }^{109}$ A A An Na'im, 'Toward a Cross-Cultural Approach to Defining International Standards of Human Rights: The Meaning of Cruel, Inhuman, or Degrading Treatment or Punishment' in A A An-Na'im (ed), Human Rights in Cross-Cultural Perspectives (1992) 19-43.
} 